\title{
Langerhans Cells in Feline Foetal Epidermis - Immunohistochemical Study of Spatial Distribution
}

\section{A. GOROŠOVÁ ${ }^{1}$, E. MATALOVÁ ${ }^{2,3}$, I. KOCIÁNOVÁ ${ }^{1}$, F. TICHÝ ${ }^{1}$}

${ }^{1}$ Institute of Anatomy, Histology, and Embryology, University of Veterinary and Pharmaceutical Sciences, Brno, Czech Republic

${ }^{2}$ Department of Physiology and Pathophysiology, University of Veterinary and Pharmaceutical Sciences, Brno, Czech Republic

${ }^{3}$ Institute of Animal Physiology and Genetics, v.v.i., Academy of Sciences, Brno, Czech Republic

Received April 17, 2007

Accepted June 11, 2008

\begin{abstract}
Gorošová A., E. Matalová, I. Kociánová, F. Tichý: Langerhans Cells in Feline Foetal Epidermis - Immunohistochemical Study of Spatial Distribution. Acta Vet. Brno 2008, 77: 307-312.

Langerhans cells belong to the skin-associated lymphatic tissue (SALT). They are antigenpresenting cells derived from monocyte precursors in the bone marrow.

The distribution of Langerhans cells was investigated in feline foetuses on day 40 of ontogenesis, in 9 selected body regions: regio intermandibularis, regio axilaris, regio prepubica, regio inguinalis, regio parietalis, regio interdigitalis, regio thoracis, regio sacralis and regio caudalis. Mouse monoclonal antibody against CD1 receptor (epitope CD1a) was applied to localize Langerhans cells in the skin samples.

The highest number of Langerhans cells was found in biopsy of the dorsal part of the feline foetuses. Langerhans cells were present particularly among keratinocytes of stratum germinativum (stratum basale and stratum spinosum), scattered or clustered among epidermal cells closing the hair canal in the region close to the hair follicle. Langerhans cells were further located among cells of outer root sheath in the region of hair follicle infundibulum close to ostium of sebaceous glands ductus, some were found also in the upper part of the hair follicle isthmus.

Langerhans cells seem to participate in skin disorders related to hypersensitivity and even tumour transformations. Distribution of these cells may play a role in disease predispositions; knowledge of the physiology and pathophysiology of Langerhans cells opens possible targeted treatments in veterinary medicine.
\end{abstract}

Skin, cat foetus, SALT, CDI

In general, skin represents an important anatomical and physiological barrier but also a communication means between organisms and their external environment. Moreover, skin is an integral part of the immune system. Different cell types present in the skin such as Langerhans cells (LC), dermal dendritic cells, epidermotropic T-lymphocytes together with skin draining lymph nodes belong to an integrated tissue system mediating skin immune protection and forming so called skin-associated lymphoid tissue (SALT) (Streilein et al. 1999).

Both innate and acquired immunity operate in close relationship open exposure of the skin to various antigens. LC stimulate proliferation of important T-helper lymphocytes by antigen presentation on their surface, thus inducing also cytotoxic T-lymphocytes to moderate the allogeneic reaction. LC produce interleukin 1 and other cytokines, moreover, they are capable of phagocytosis and contain many different enzymes (Goodell et al. 1985).

LC stem cells originate from pluripotent hematopoietic progenitor cells CD34+ in the bone marrow. Recent results identified monocytes with a high expression of Gr-1 $(\mathrm{Ly}-6 \mathrm{c} / \mathrm{G})$ marker as the direct precursors for LC in vivo and showed the importance of the colony- 
stimulating factor 1 (CSF-1) in this process (Ginhoux et al. 2006). As immature cells, LC migrate to non-lymphatic tissues, such as the skin, where they finish their maturation by expression of specific molecules (ATPase, CD45, MHC II, langerin/CD207) and formation of the Birbeck granules (Elbe et al. 1989; Foster and Holbrook 1989; Koch et al. 2006). The Birbeck granula, characteristic structures in LC, were described as para-crystallic, membrane-bound, disc-shaped bodies, and are located particularly between the cell membrane and the Golgi apparatus (Holibka 1998).

Langerhans cells in the cat skin were first described by Tsagarakis et al. (1994). LC were detected in adult skin using TEM and immunohistochemistry, and were found in the epidermis and in the oral, vaginal, rectal and oesophageal mucosa. Later immunophenotypic characterisations of feline Langerhans cells were performed (Marchal et al. 1997) and gene expression in Langerhans cells analyzed (Rust et al. 2006).

The biology of LC in adults has been recently reviewed (Bechan et al. 2006) and interactions of different cells in pathophysiology of Langerhans cell histiocytosis discussed. However, there is insufficient information on foetal migration and location of Langerhans cells in the skin. Therefore, this study aims to demonstrate the distribution and specific locations of Langerhans cells in feline foetal skin in order to better understand the involvement of Langerhans cells in the skin development with possible further contributions to veterinary treatments.

\section{Materials and Methods}

Specimens

Investigated tissues were collected from 3 foetuses on day 40 of ontogenesis (DO). The foetuses were obtained from the Small Animal Clinic, University of Veterinary and Pharmaceutical Sciences, Brno. The foetuses were euthanized using T-61 (Intervet, Germany) after umbilical cord cut. Nine selected skin areas were harvested immediately after euthanasia and immersed into liquid nitrogen. Serial sections $(10 \mu \mathrm{m})$ were split over 2 slides and prepared for further analyses.

Antibodies

Specific mouse monoclonal antibodies for CD antigen detections in cats were obtained from the School of Veterinary Medicine, University of California, Department of Pathology, Davis, California, USA. To precise the localization of Langerhans cells, two epitopes of the CD molecule were detected - CD1a (Fe1.5F4). The monoclonal antibody was used at a $1: 10$ dilution.

Immunohistochemistry

Monoclonal antibody (MAb) was applied for $1 \mathrm{~h}$ at the room temperature. Secondary antibody against mouse IgG labelled by peroxidase (Vectastain ABC-Peroxidase kit mouse IgG, VC-PK-4002-KI01, Diagenes) was applied for $30 \mathrm{~min}$. This reagent was a $1: 400$ dilution of antibody diluent (S 3022, Dako). Endogenous peroxidase was quenched in $3.0 \%$ hydrogen peroxide in PBS for 5 min at room temperature. The colour reaction mediated by diaminobenzidine (Liquid DAB+, K 3468, Dako) as the substrate enabled visualisation of Langerhans cells in the skin. Positive cells were brown; the slides were counterstained by Mayer's haematoxylin.

\section{Results}

Regio intermandibularis

LC were found scattered in small clusters in stratum germinativum of the epidermis and in the epithelial part of the hair follicle infundibulum, close to sebaceous glands (Plate I, Fig. 1).

Regio axilaris

LC were scattered among keratinocytes of stratum germinativum, some individual CD1a positive cells were found also in the dermis around hair follicles (Plate I, Fig. 2).

Regio prepubica

LC were detected in clusters among cells of stratum germinativum of epidermis. None or only few positive cells were found in the dermis (Plate II, Fig. 3). 


\section{Regio inguinalis}

Only few positive cells were found in this region, particularly scattered in stratum germinativum and stratum granulosum, in the dermis, positive cells were found exclusively around hair follicles (Plate II, Fig. 4).

Regio parietalis

LC were found individually or clustered in stratum germinativum of the epidermis and also in the dermis in the region of the hair follicle infundibulum close to the ostium of sebaceous glands (Plate III, Fig. 5).

Regio interdigitalis

LC were scattered among cells of stratum germinativum, located around hair follicles, and rarely also in the superficial dermis (Plate III, Fig. 6).

\section{Regio vertebralis thoracis}

LC formed cell clusters in the epidermis located in areas of hair germs, very few LC were found in the superficial dermis close to the hair follicle infundibulum (Plate IV, Fig. 7).

\section{Regio pelvina}

LC were present among keratinocytes in stratum germinativum of the epidermis, mostly forming clusters. Positive cells in the dermis were detected close to the hair follicle isthmus (Plate IV, Fig. 8).

\section{Regio radicis caudae}

LC in stratum germinativum were present in cell clusters rather than individually. LC in the dermis were found among cells of the outer epithelial sheath in the area of the infundibulum of hair follicles (Plate V, Fig. 9).

Comparison of different body surface regions of feline foetuses at $40 \mathrm{DO}$ showed the LC distributed particularly in the dorsal body parts of the foetuses, in the areas of regio parietalis, vertebralis thoracis, pelvina and radicis caudae. In the epidermis, LC were located particularly among keratinocytes of stratum germinativum (stratum basale and stratum spinosum), scattered or clustered among epidermal cells closing the hair canal in the region around the hair follicle. In the dermis, LC were found particularly among cells of outer root sheath in the region of the hair follicle infundibulum close to the ostium of sebaceous gland ductus, some were found also in the upper part of the hair follicle isthmus.

\section{Discussion}

Compared to much data obtained in vitro, only few observations point to the function of Langerhans cells (LC) in vivo (Romani et al. 2006). There is also a lack of evidence about the timing of LC appearance during prenatal development and their spatial distribution.

LC were demonstrated in an 18-week-old human foetus in the tonsilla palatina epithelium (Holibka 1998). In a marsupial (Dasyurus hallucatus), LC were found in epidermis only after 23 days post partum (Pralomkarn et al. 1990). In both cases, the appearance of LC seems to correlate with the timing of hair formation. A higher density of LC was reported in the hair canal before opening in the human foetal dermis (Chang et al. 2005). To obtain evidence about foetal distribution of LC in pets at the stage of hair follicle formation, feline foetal skin on day 40 of ontogenesis ( $40 \mathrm{DO}$ ) was investigated in our study. On $30 \mathrm{DO}$ the formation of protective hair starts in the feline foetal dermis and on $39 \mathrm{DO}$ macroscopically distinguishable white spots created by growing protective hair can be seen in the epidermis. The protective hair reaches the body surface around $50 \mathrm{DO}$ and the furring continues up to $3 \mathrm{~mm}$ long hair. The hair density differs in different parts of the feline foetus, with more distant hair in the lateral regions and in limbs and higher hair density in the dorsal regions of the body. 
The results yielded from the comparison of nine different body surface regions of feline foetuses on $40 \mathrm{DO}$ showed the LC distributed particularly in the dorsal body parts of the foetus, in the areas of regio parietalis, vertebralis thoracis, pelvina and radicis caudae. These findings support the idea of a relationship between LC density and hair follicles distribution because in all these regions the thick type epidermis and distinct furring can be found. The described observations must be considered also in the view of Langerhans cells as sentinel cells whose prime function is the surveillance of the epidermal environment and initiation of immune response against microbial threats (Romani et al. 2006). The hair follicles constitute an easy way for microbes to gain entry into the skin, particularly during the microbial colonization of the skin after birth (Marchini et al. 2005). Therefore, LC homing seems to correlate with these protection desiring regions. Moreover, clusters of $\mathrm{LC}$ in the interfollicular epidermis and among keratinocytes in the region of the hair follicle infundibulum may correlate with sites called EPU (epidermal proliferative unit). The EPU serves as an important source of stem cells and contributes to the tissue stability maintenance and cell proliferation control (Kaur 2006).

Langerhans cells seem to be involved in the pathogenesis of skin disorders evoked by hypersensitivity to local and systemic allergens (Toews et al. 1980; Streilein et al. 1982), including atopic dermatitis (Roosje at al. 1997). Increased numbers of Langerhans cells in the epidermis and dendritic cells in the dermis were demonstrated in atopic skin lesions of experimental animals. Moreover, an increased number of LC in the epidermis was found also during some immune diseases, e. g. lupus erythematosus, hypersensitive dermatitis, and pyodermia (Day 1996). Neoplastic transformations of LC exist in dogs, e.g. canine cutaneous histiocytoma (CCH), a malignant histiocytosis (Affolter and Moore 2000, 2002). Symptoms and immunosuppressive mediated response correspond to disorders in the immune system regulations. Thus, LC and dendritic cells are in focus in tumour research and therapy (Yoshida et al. 2003).

An active role in epidermal immunity is also played by epidermal keratinocytes. These cells produce interleukin 1, interleukin 3, prostaglandins, leukotriens and interferons. Keratinocytes may fulfil phagocytosis and thus present antigens connected with lymphocyte-mediated skin diseases (probably as a result of $\gamma$-interferon secretion by activated lymphocytes). LC make an adhesive contact with keratinocytes by molecules of E-cadherin (Teunissen et al. 1994). Moreover, LC and lymphocytes seem to communicate by soluble and membrane-bound molecules to make both cell types more active (Rotsztejn et al. 2006). Therefore, skin immunity, and particularly keratinocytes and Langerhans cells are of major research interest in human as well as veterinary medicine of pets (Scott et al. 1995). Moreover, due to the immunophenotypic and ultrastructural similarity of human and feline Langerhans cells, some applications may be extrapolated among the species (Marchal et al. 1997).

\section{Langerhansovy buňky v kočičí fetální epidermis - immunohistochemická studie prostorového rozložení}

Langerhansovy buňky jsou součástí imunitního systému v rámci SALT (skin-associatedlymphatic tissue) a patři mezi antigen prezentující buňky diferencované z monocytových prekurzorů kostní dřeně.

Výskyt Langerhansových buněk byl studován v kůži fétů kočky ve stář́ 40 dnů intrauterinního vývoje, a to v 9 vybraných tělních krajinách: regio intermandibularis, regio axilaris, regio prepubica, regio inguinalis, regio parietalis, regio interdigitalis, regio thoracis, regio sacralis a regio caudalis. Pro specifické značení Langerhansových byla využita myší monoklonální protilátka specifická proti antigenu CD1 (epitop CD1a).

Ve sledovaném intrauterinním období byl četnější výskyt Langerhansových buněk v kožních bioptátech odebraných z dorzálních oblastí kožního pokryvu kočičích fétů. 
Langerhansovy buňky byly $\mathrm{v}$ epidermis přitomny především mezi keratinocyty stratum germinativum (stratum basale a stratum spinosum), jednotlivě i ve shlucích mezi epidermálními buňkami, které uzavíraly chlupový kanál v místě vyústění chlupového folikulu. V dermis byly Langerhansovy buňky prokázány nejčastěji mezi buňkami zevní epitelové pochvy v oblasti infundibula chlupového folikulu těsně nad vyústěním vývodu gl. sebacae, méně pak v horní části isthmu chlupového folikulu. V kožních bioptátech z dorzálních kožních regionů byly Langerhansovy buňky př́itomny i difúzně rozptýlené $\mathrm{v}$ dermis $\mathrm{v}$ okolí chlupových folikulů.

Langerhansovy buňky participují v řadě kožních onemocnění spojených s hypersenzitivitou, atopickými dermatitidami i s nádorovými transformacemi. Embryonální distribuce těchto buněk může hrát roli v lokálních predispozicích, znalost fyziologie a patofyziologie Langerhansových buněk pak otevírá cestu k cíleným léčebným zásahům ve veterinární medicíně.

\section{Acknowledgement}

This study was supported by the grant IGA VFU, project IG $151111-19 / 2005$

\section{References}

AFFOLTER VK, MOORE PF 2000: Canine cutaneous and systemic histiocytosis. Reactive histiocytosis of dermal dendritic cells. Am J Dermatopathol 22: 40-48

AFFOLTER VK, MOORE PF 2002: Localized and disseminated histiocytic sarcoma of dendritic cell origin in dogs. Vet Pathol 39: 74-83

BECHAN GI, EGELER RM, ARCECI RJ 2006: Biology of Langerhans cells and Langerhans cell histiocytosis. Int Rev Cytol 254: 1-43

DAY MJ 1996: Expression of major histocompatibility complex class II molecules by dermal inflamatory cells, epidermal Langerhans cells and keratinocytes in canine dermatological disease. J Comp Pathol 115: $317-326$

ELBE A, TSCHACHLER E, STEINER G, BINDER A, WOLFF K, STINGL G 1989: Maturational step of bone marrow-derived dendritic murine epidermal cells. Phenotypic and functional studies on Langerhans cells and Thy-1+ dendritic epidermal cells in the perinatal period. J Immunol 143: 2431-2438

FOSTER CA, HOLBROOK KA 1989: Ontogeny of Langerhans cells in human embryonic and fetal skin: cell densities and phenotypic expression relative to epidermal growth. Am J Anat 184: 157-164

GINHOUX F, TACKE F, ANGELI V, BOGUNOVIC M, LOUBEAU M, DAI XM, STANLEY ER, RANDOLPH GJ, MERAD M 2006: Langerhans cells arise from monocytes in vivo. Nat Immunol 7: 265-273

GOODELL EM, BLUMENSTOCK DA, BOWERS WE 1985: Canine dendritic cells from peripheral blood and lymph nodes. Vet Immunol Immunopathol 8: 301-310

HOLIBKA V 1998: Langerhans cells in the epithelium of the human palatine tonsil during the prenatal development. Acta Univ Palacki Olomuc Fac Med 141: 41-43

CHANG CH, TSAI RK, YU HS 2005: Apoptosis coordinates with proliferation and differentiation during human hair follicle morphogenesis. J Dermatol Sci 39: 9-16

KAUR P 2006: Interfollicular epidermal stem cells: Identification, challenges, potential. J Invest Dermatol 126: 1450-1458

KOCH S, KOHL K, KLEIN E, VON BUBNOFF D, BIEBER T 2006: Skin homing of Langerhans cell precursors: adhesion, chemotaxis, and migration. J Allergy Clin Immunol 117: 163-168

MARCHAL SAINT-ANDRE I, DEZUTTER-DAMBUYANT C, MARTIN JP, WILLET BJ, WOO JC, MOORE PF, MAGNOL JP, SCHMITT D, MARCHAL T 1997: Quantitative assessment of feline epidermal Langerhans cells. Br J Dermatol 136: 961-965

MARCHINI G, NELSON A, EDNER J, LONNE-RAHM S, STAVREUS-EVERS A, HULTENBY K 2005: Erythema toxicum neonatorum is an innate immune response to commensal microbes penetrated into the skin of the newborn infant. Pediatr Res 58: 613-616

PRALOMKARN T, NELSON J, GEMMEL RT 1990: Postnatal development of the skin of the marsupial native cat Dasyurus hallucatus. J Morphol 205: 233-242

ROMANI N, EBNER S, TRIPP CH, FLACHER V, KOCH F, STOITZNER P 2006: Epidermal Langerhans cells - changing views on their function in vivo. Immunol Lett 106: 119-125

ROOSJE PJ, WHITAKER-MENEZES D, GOLDSCHMIDT MH, MOORE PF, WILLEMSE T, MURPHY GF 1997: Feline atopic dermatitis. A model for Langerhans cell participation in disease pathogenesis. Am J Pathol 151: $927-932$

ROTSZTEJN H, TRZNADEL-BUDŽKO E, JESIONEK-KUPNICKA D 2006: Langerhans cells in vulvar lichen sclerosus and vulvar squamous cell carcinoma. Arch Immunol Ther Exp 54: 363-366 
RUST R, KLUIVER J, VISSER L, HARMS G, BLOKZIJL T, KAMPS W, POPPEMA S, VAN DEN BERG A 2006: Gene expression analysis of dendritic/Langerhans cells and Langerhans cell histiocytosis. J Pathol 209: 474-483

SCOTT PG, DODD CM, TREDGET EE, GHAHARY A, RAHEMTULLA F 1995: Immunohistochemical localization of the proteoglycans decorin, biglycan and versican and transforming growth-factor-beta in human postburn hypertrophic and mature scars. Histopathology 26: 423-431

STINGL G, WOLFF-SCHREINER EC, PICHLER WJ, GSCHNAIT F, KNAPP W, WOLFF K 1977: Epidermal Langerhans cells bear Fc and C3 receptors. Nature 268: 245-246

STREILEIN JW, ALARD P, NIIZEKI H 1999: A new concept of skin-associated lymphoid tissue (SALT): UVB light impaired cutaneous immunity reveals a prominent role for cutaneous nerves. Keio J Med 48: 22-27

STREILEIN JW, LONSBERRY LW, BERGSTRESSER PR 1982: Depletion of epidermal Langerhans cells and Ia immunogenicity from tape-stripped mouse skin. J Exp Med 155: 863-871

TEUNISSEN MB, RONGEN HA, BOS JD 1994: Function of adhesion molecules lymphocyte functionassociated antigen-3 and intercellular adhesion molecule-1 on human epidermal Langerhans cells in antigenspecific T cell activation. J Immunol 152: 3400-3409 TOEWS GB, BERGSTRESSER PR, STREILEIN JW 1980: Epidermal Langerhans cell density determines whether contact hypersensitivity or unresponsiveness follows skin painting with DNFB. J Immunol 124: 445-453

SAGARAKIS C, MARCHAL T, MAGNOL JP, FOURNEL C, DEZUTTER-DAMBUYANT C, SCHMIDT D 1994: Contribution of the feline Langerhans cell to the FIV model. Res Virol 145: 245-249

YOSHIDA H, MOMOI Y, TAGA N, IDE K, YAMAZOE K, IWASAKI T, KUDO T 2003: Generation of canine dendritic cells from peripheral blood mononuclear cells. J Vet Med Sci 65: 663-669 
Plate I

Gorošová A. et al.: Langerhans cells ... pp. 307-312

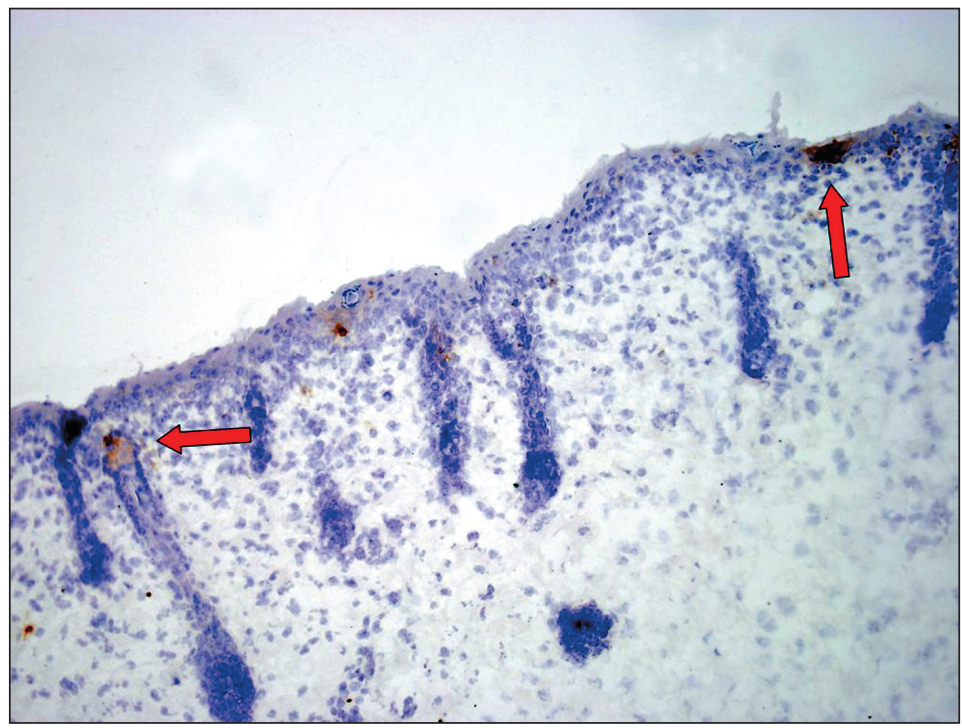

Fig. 1. Foetus, cat, regio intermandibularis, $\times 200$. CD1 a positive cells in stratum germinativum of epidermis and in epithelial part of hair follicle infundibulum (arrows).

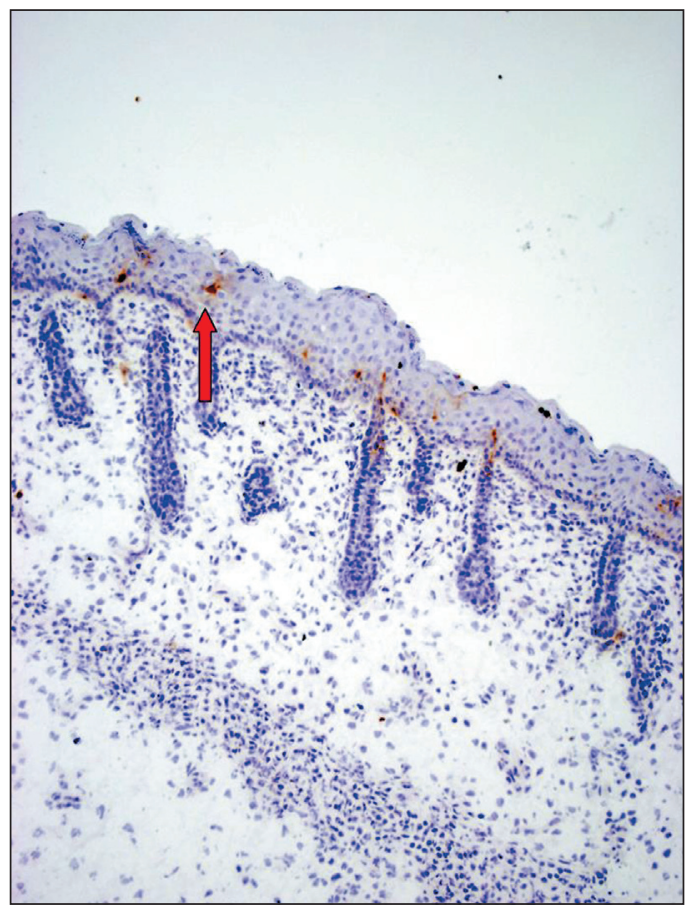

Fig. 2. Foetus, cat, regio axilaris, $\times 200$. CD1a positive cells in stratum germinativum (arrow). 


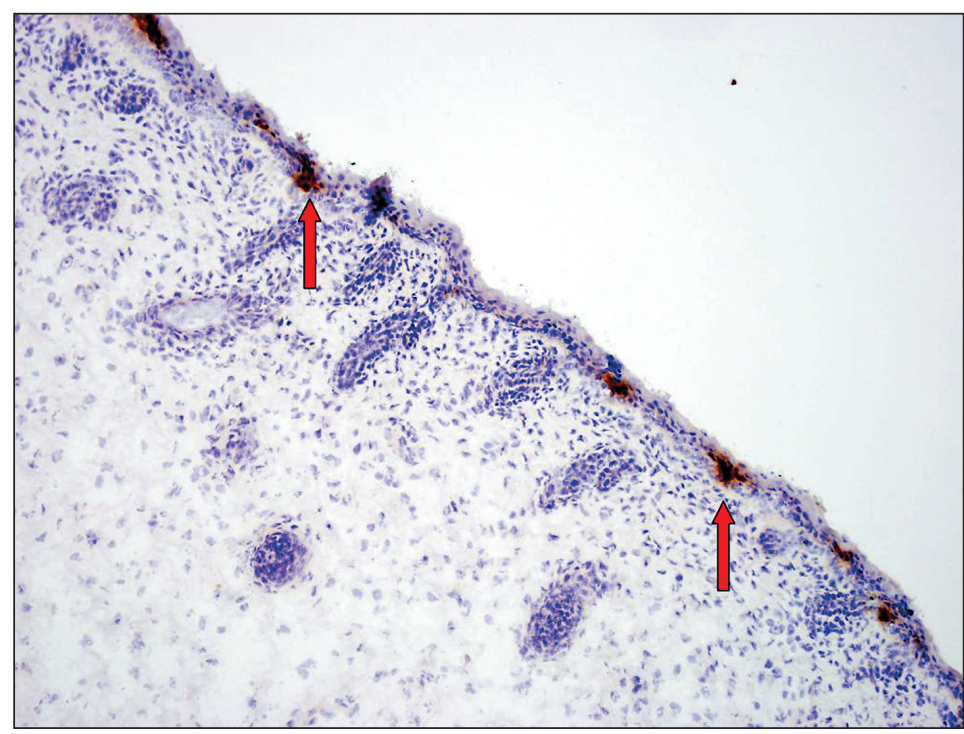

Fig. 3 Foetus, cat, regio prepubica, $\times 200$. CD1a positive cells in clusters among cells of stratum germinativum of epidermis (arrows).

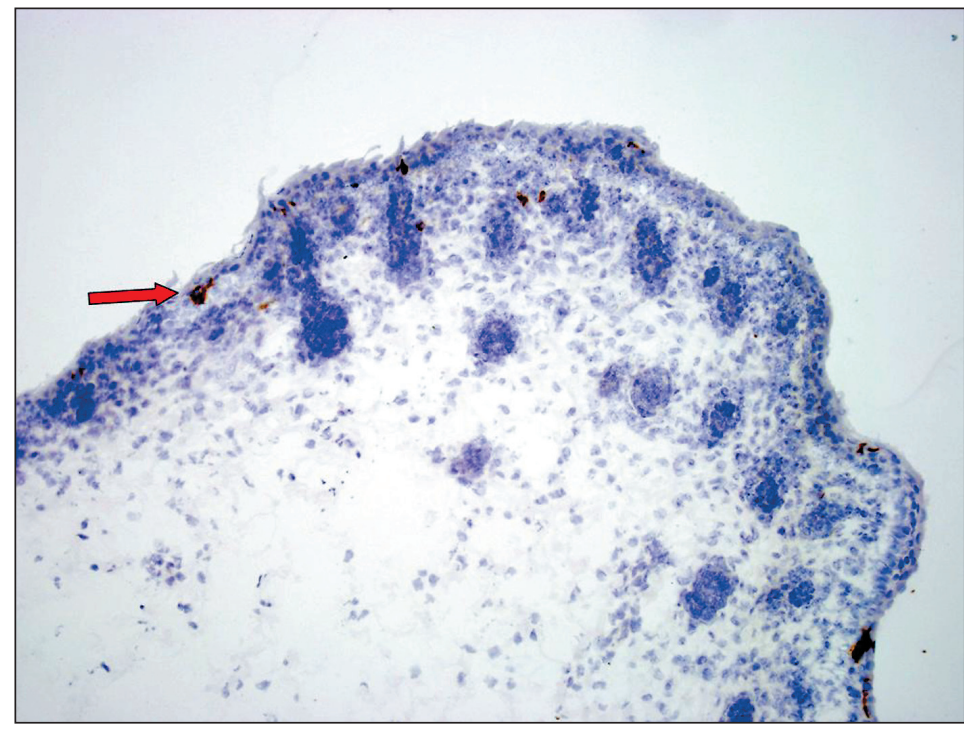

Fig. 4. Foetus, cat, regio inguinalis, $\times 200$. Just a few of CD1a positive cells were found in this region (arrow). 


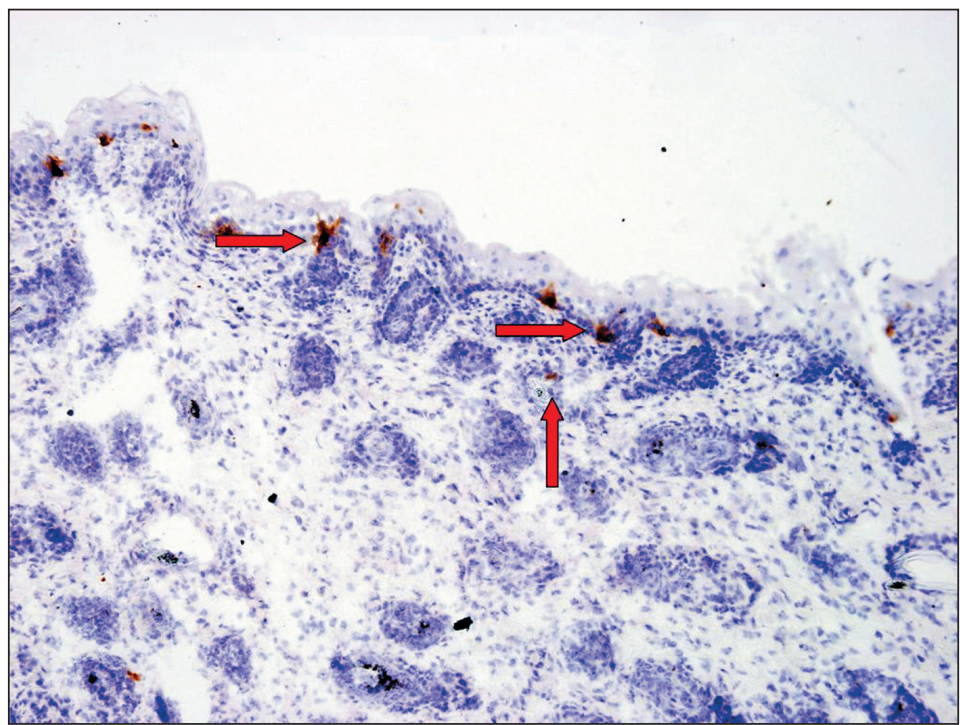

Fig. 5. Foetus, cat, regio parietalis, $\times 200$. CD1a positive cells were found individually or clustered close to hair follicles and sebaceous glands in stratum germinativum of epidermis, some small number also in dermis (arrows).

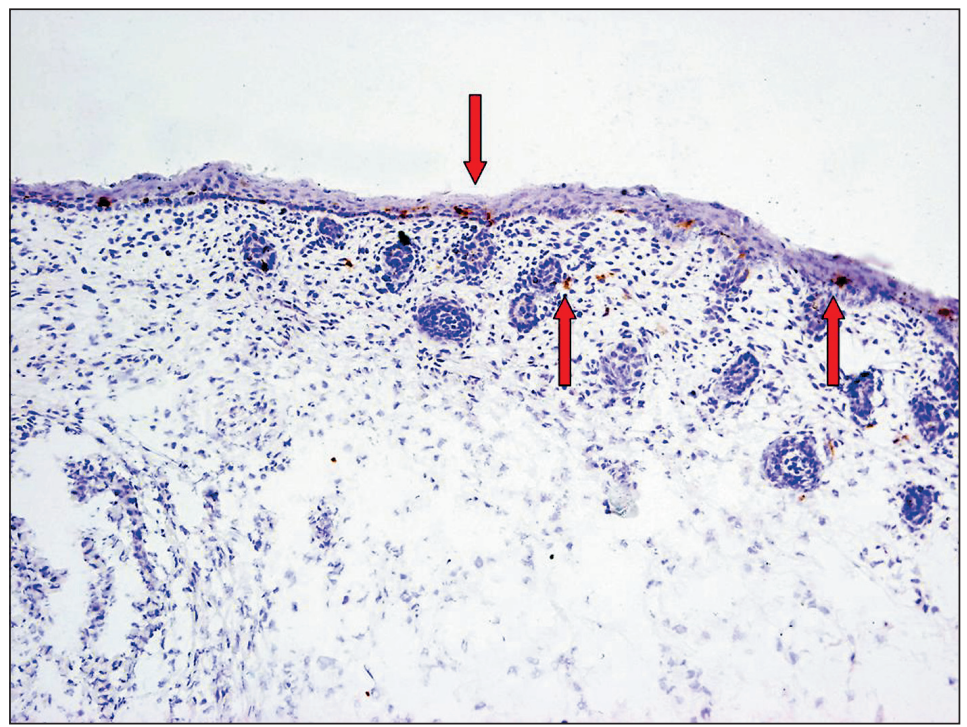

Fig. 6. Foetus, cat, regio interdigitalis, $\times 200$. CD1a positive cells were scattered among cells of stratum germinativum and they were also diffused in dermis around the hair follicle (arrows). 


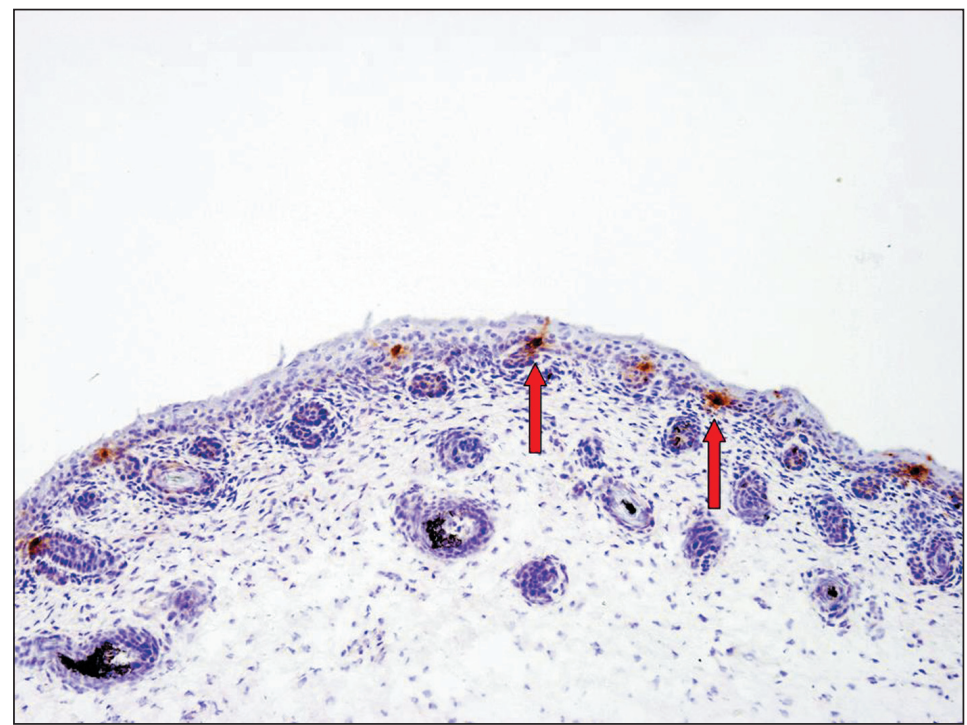

Fig. 7. Foetus, cat, regio vertebralis thoracis, $\times 200$. CD1 a positive cells were found in superficial dermis close to hair follicle infundibulum (arrows).

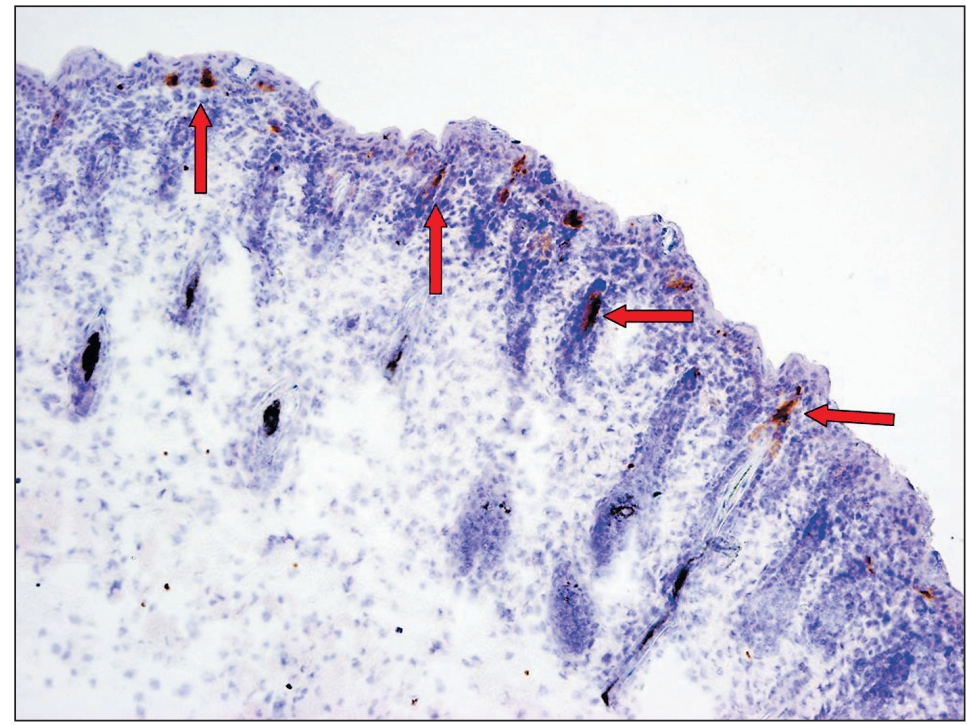

Fig. 8. Foetus, cat, regio pelvina, $\times 200$. CD1a positive cells were detected close to hair follicle infundibulum and isthmus, mostly forming clusters (arrows). 


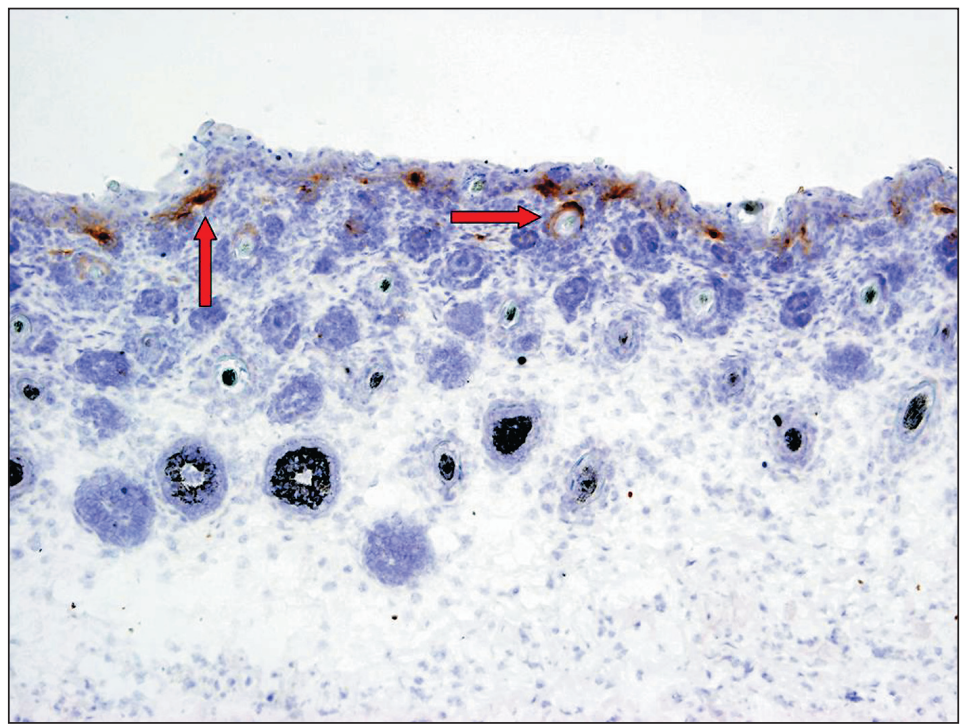

Fig. 9 Foetus, cat, regio radicis caudae, $\times 200$. CD1a positive cells were present in cell clusters rather than individually. In dermis they were found among cells of the outer epithelial sheath in the area of the infundibulum of hair follicles (arrows). 